University of Arkansas at Little Rock William H. Bowen School of Law Bowen Law Repository: Scholarship \& Archives

Faculty Scholarship

2014

\title{
Texting and the Friction of Writing
}

Lindsey P. Gustafson

lpgustafson@ualr.edu

Follow this and additional works at: http://lawrepository.ualr.edu/faculty_scholarship

Part of the Legal Writing and Research Commons

Recommended Citation

Lindsey P. Gustafson, Texting and the Friction of Writing, 19 Legal Writing: J. Legal Writing Inst. 161 (2014).

This Article is brought to you for free and open access by Bowen Law Repository: Scholarship \& Archives. It has been accepted for inclusion in Faculty Scholarship by an authorized administrator of Bowen Law Repository: Scholarship \& Archives. For more information, please contact mmserfass@ualr.edu. 


\title{
TEXTING AND THE FRICTION OF WRITING
}

\author{
Lindsey P. Gustafson*
}

Does the medium an author uses to communicate alter the shared ideas themselves? Generations of thinkers and educators have believed so: Plato worried that reliance on written, rather than oral communication, would impair memory-"[t]his invention will produce forgetfulness in the minds of those who learn to use it, because they will not practice their memory" 1 -and that, because it was one-sided and could not respond to questions, it was less effective and trustworthy than speech. ${ }^{2}$ In the late eighteenth century, after decades of instructing students to "think before you write," teachers worried that with the invention of the pencil with an attached eraser, students would be less careful in their composition and more likely to make errors. ${ }^{3}$ In 1882 , when philosopher Friedrich Nietzsche bought his first typewriter, his contemporaries noticed the change in his style of writing. ${ }^{4}$ One modern scholar argues that, with the transition to a typewriter, Nietzsche's prose "changed from arguments to aphorisms, from thoughts to puns, from rhetoric to telegram style."

But there was no going back for Plato or for Nietzsche (whose failing vision and resulting headaches made handwriting increasingly painful), and there is no going back for us. We are engulfed

* (c) 2014, Lindsey P. Gustafson. All rights reserved. Associate Professor of Law, William H. Bowen School of Law, University of Arkansas at Little Rock. The Author wishes to thank Professor Coleen Barger, who started this research with me and is a consistent source of ideas and encouragement; Stefan McBride for his research; and the UALR Bowen School of Law for its generous research grant.

1. Plato, Plato in Twelve Volumes, vol. 9 (Harold N. Fowler trans., Harvard U. Press 1925) (c. 360 B.C.E.) (expressed through a dialogue between Socrates and Phaedrus).

2. Id.; see also Dennis Baron, A Better Pencil: Readers, Writers, and the Digital Revolution 3-4 (Oxford U. Press 2009).

3. Baron, supra n. 2, at 44.

4. Friedrich Kittler, Gramaphone, Film, Typewriting 203 (Geoffrey Winthrop-Young trans., Stanford U. Press 1999).

5. Id.; see also Nicholas Carr, Is Google Making Us Stupid? Atlantic Mag. (July 1, 2008) (available at http://www.theatlantic.com/magazine/archive/2008/07/is-google-making -us-stupid/306868/) (using the example of Nietzsche as evidence that the "human brain is almost infinitely malleable"). 
in technology's "fifth wave," 6 and "mobile phones have permeated almost every facet of interpersonal interaction in an apparent melding of humanity and technology."7 Typewriters may not have reached the level of ubiquity that would have made handwriting obsolete, but computers have: Digital natives are growing up with computers in school, computers at home, computers in their pockets, and they use them to write, often. ${ }^{8}$ A 2011 study found that 95 percent of the surveyed 18-24 year olds had mobile phones, and that 97 percent of the phone owners use text messaging; ${ }^{9}$ adolescents who have grown up with this technology (and many adults) view texting as an "integral aspect of the sense of self." 10 What might be the consequence of becoming so familiar with, probably reliant upon, this medium of communication? Surely some good. But, as Sophocles warned, "Nothing that is vast enters into the life of mortals without a curse."11

Of course a new literacy (like texting) need not be oppositional to a traditional literacy (like written legal argument). ${ }^{12}$ The

6. "Technology's fifth wave, fueled by cheap, powerful handheld computers and broadband Internet access, is an 'epic technological transformation' comparable to the introduction of mainframes in the 1960s, minicomputers in the 1970s, personal computers in the 1980s, and networking and the Internet in the 1990s." See Wade Roush, Computing's Fifth Wave, MIT Tech. Rev. (July 7, 2005) (available at http://www .technologyreview.com/view/404408/computings-fifth-wave/).

7. Dorothy Skierkowski \& Rebecca M. Wood, To Text or Not to Text? The Importance of Text Messaging among College-Aged Youth, 28 Computers in Human Behavior 744, 744 (2012).

8. See Kristen Purcell et al., How Teachers Are Using Technology at Home and in Their Classrooms, http://www.pewinternet.org/Reports/2013/Teachers-and-technology.aspx (Feb. 28, 2013) (describing how the Internet and mobile technology has become central to the learning process). Many grade schools have discontinued handwriting instruction in favor of keyboarding, even though recent studies have shown a link between letter formation and literacy. See Kyle Stokes, Why Schools Should Keep Teaching Handwriting, Even If Typing Is More Useful, http://indianapublicmedia.org/stateimpact/2011/09/29/why. schools-should-keep-teaching-handwriting-even-if-typing-is-more-useful (Sept. 29, 2011).

9. Aaron Smith, Pew Research Ctr., Americans and Text Messaging: How Americans Use Text Messaging, http://www.pewinternet.org/2011/09/19/how-americans-use-textmessaging/ (Sept. 19, 2011).

10. Skierkowski \& Wood, supra n. 7, at 746.

11. Sophocles, Antigone, in Great Books of the Western World 131, 136 (Robert Maynard Hutchins ed., Encyclopedia Brittanica 1952).

12. See Gloria E. Jacobs, We Learn What We Do: Developing a Repertoire of Writing Practices in an Instant Messaging World, $52 \mathrm{~J}$. of Adolescent \& Adult Literacy 203, 204 (Nov. 2008). Jacobs recognizes that literacies may be viewed as complementary when they have the potential to open up a wide range of opportunities for youths to engage in literacy practices beyond what traditionally has been available in schools; literacies may be oppositional when youths may lose the motivation to learn traditional literacies if the new literacies gain in value; and literacies may be mutually exclusive when the new literacy practic- 
literacies may be complementary: We are, after all, reading and writing more than ever. A 2012 survey of technology experts and various stakeholders (including teachers) on the impact of the "'always-on' connectivity" of young people showed a fairly even split between those who predicted positive results from the connectivity and those who predicted negative results. ${ }^{13}$ This split is reflected broadly across the relevant literature; experts appear to be following their own natural optimistic or pessimistic tendencies in their predictions. ${ }^{14}$ For example, as early as 2002 , surveyed teachers were split, with some expressing frustration over a growing use of informal language, and others predicting that students' familiarity with text would make them better able to brainstorm and to use writing to spark their thinking process. ${ }^{15}$

The perils and promises of a rising generation steeped in informal writing are particularly relevant to legal educators: Not only are we engaged in training students to be professional readers and writers who will carefully use written language to explain, to persuade, or to bind others, we frequently encourage students to use the rigor of writing to build their understanding and to create complex legal argument. When writing is difficult, it is the "friction" that forces us to name our free-flowing ideas and to link them into clear, coherent text. The friction of writing therefore acts to deepen and clarify ideas.

es will be appropriated as we attempt to transfer them into the classroom. Id.

13. Janna Anderson \& Lee Raine, Pew Research Ctr,, Millennials Will Benefit and Suffer Due to Their Hyperconnected Lives 2, http://pewinternet.org/Reports/2012/ Hyperconnected-lives.aspx (Feb. 29, 2012). Some of the uncertainty in interpreting the data and predicting future impact is caused by the unprecedented speed of the changes in available technologies and the corresponding habits of the users. And some of it is just the relative age of the technology: text messaging turned 20 in 2012. See Heather Kelly, $O M G$, The Text Message Turns 20. But Has SMS Peaked? http://www.cnn.com/2012/12/03/ tech/mobile/sms-text-message-20/ (Dec. 3, 2012).

14. Compare David Crystal, Txtng: The gr $8 \mathrm{db} 8$, at 9 (Oxford U. Press 2008) (characterizing "moral outrage" against texting and quoting broadcaster John Humphreys who claimed that texters are "vandals who are doing to our language what Genghis Khan did to his neighbours eight hundred years ago. They are destroying it: pillaging our punctuation; savaging our sentences; raping our vocabulary. And they must be stopped."), with Crispin Thurlow, From Statistical Panic to Moral Panic: The Metadiscursive Construction and Popular Exaggeration of New Media Language in the Print Media, $11 \mathrm{~J}$. of ComputerMediated Commun. 667, 688 (2006) (noting that it is "likely from a sociolinguistic and scholarly point of view that language and communication are changing and evolving as they always have").

15. Jennifer Lee, I Think, Therefore IM, N.Y. Times (Sept. 19, 2002) (available at http://www.nytimes.com/2002/09/19/technology/i-think-therefore-im.html). 
While it may be true that a student who enters law school an "expert" in informal writing will be less likely to use language carefully and less likely to feel the rigor of writing, it may also be true that such a student is adept at writing to different audiences and has a habit of writing that will move her past the writer's block many of us felt years ago, facing a typewriter.

Whatever the impact, we will be better able to adjust our teaching if we can move past the uninformed assumptions we make about informal writing-that it weakens linguistic skills and tolerates sloppy composition-to predict, as specifically as possible, informal writing's impact on more formal writing as the "generation text" moves into law school. To better inform our teaching, this Article first describes the current preference for informal writing among our students (an admittedly moving target), and then summarizes relevant data from composition studies, most often conducted on students from the ages of ten to twenty-five. The Article then uses this data to address these primary concerns: (1) whether frequent exposure to and use of text speak $^{16}$ weakens general language acquisition and students' growth as expert legal writers and readers; and (2) whether the ease of texting will make students accustomed to quick, easy writing, and will thereby compromise students' ability to use writing to work through and solve problems.

The Article concludes with a perhaps unexpected reason to celebrate the rise of informal writing and to encourage the transfer of skills from informal to more formal legal writing. Not only may transfer allow students to build on any relevant skills they have developed through informal writing, students benefit emotionally from identifying themselves as writers with experience that may help them address a legal audience. When new law students know they are already part of a community of writers, this knowledge may not only relieve students' anxiety about learning a new form of writing, but also give them a greater awareness of their linguistic options and how to use them to meet the needs of their new, law-trained audience.

16. The unique language of texting is referred to by many names, including "textese," "textisms," and "text speak." This Article will refer to it as "text speak." 


\section{STUDENTS' GROWING PREFERENCE FOR TEXTING OVER ALL OTHER FORMS OF COMMUNICATION}

For most people in the world, cell phones have become an expected, essential appendage. As of 2012, there were six billion mobile cellular subscriptions worldwide; ${ }^{17}$ an estimated 85 percent of United States adults own cell phones. ${ }^{18}$ The applications for cell phones and related technology change rapidly, but two characteristics of the current state of technology usage are worth highlighting: (1) texting ${ }^{19}$ and related informal messaging dominates cell phone use, with young people preferring it to all other methods of communication; and (2) older generations are increasing their informal writing at a slower rate than younger generations, so the generational disparity between each group's preferred and practiced forms of communication is growing.

While we are all dramatically ramping up our informal writing-80 percent of American cell phone owners text, up from 58 percent in $2007^{20}$ - teenagers are the rock stars of texting. We are witnessing "a new generation of teenage writers, accustomed to

17. See Intl. Telecomm. Union, Measuring the Information Society 2012: Executive Summary 1 (2012) (available at http://www.itu.int/dms_pub/itu-d/opb/ind/D-IND-ICTOI2012-SUM-PDF-E.pdf) (counting SIM cards and accounts, not surveying individuals). The same report estimated that 75 percent of the world has access to mobile phones. Id. at 2 .

18. Maeve Duggan \& Lee Rainie, Pew Research Center, Cell Phone Activities 2012, http://www.pewinternet.org/2012/11/25/cell-phone-activities-2012/ (Nov 25, 2012).

19. While this Article focuses on texting because it is the informal writing most frequently used, "Tweeting" (sending out brief messages to "followers") has risen remarkably. As of May 2013, 72 percent of online adults use social networking sites, and 18 percent use Twitter. Joanne Brenner \& Aaron Smith, Pew Research Center, 72\% of Online Adults Are Social Networking Site Users, http://pewinternet.org/Reports/2013/social-networkingsites.aspx (Aug. 5, 2013). Teens and young adults, also known as "millennials," are the most likely to use Twitter. See Aaron Smith \& Joanna Brenner, Pew Research Center, Twitter Use 2012, http://www.pewinternet.org/2012/05/31/twitter-use-2012/ (May 31, 2012); Paresh Dave, Nearly One in Five U.S. Adults Online Use Twitter, Survey Finds, L.A. Times (Aug. 5, 2013) (available at http://www.latimes.com/business/technology/la-fi-tntwitter-use-up-survey-20130805,0,113872.story\#axzz2toMiw1U) (reporting that 30 percent of millennials are active on Twitter).

20. Duggan \& Rainie, supra n. 18; see also Pew Research Ctr., Mobile Technology Fact Sheet: Highlights of the Pew Internet Project's Research Related to Mobile Technology, http://www.pewinternet.org/fact-sheets/mobile-technology-fact-sheet/ (accessed Feb. 19, 2014) (finding that 91 percent of American adults have a cell phone and 81 percent text). Texting is also a worldwide phenomenon; in twenty-one countries recently surveyed, a median of 75 percent of cell phone owners say they text. Pew Research Ctr., Global Digital Communication: Texting, Social Networking Popular Worldwide, http://www.pewglobal .org/2011/12/20/global-digital-communication-texting-social-networking-popular-orldwide/ (Feb. 29, 2012). 
translating their every thought and feeling into words. They write more than any generation has since the days when telephone calls were rare and the mailman rounded more than once a day." 21

The raw numbers of teenage texting are striking. A recent survey of adults found that 95 percent of young adults between the ages of eighteen and twenty-four (the youngest age group in the survey) own cell phones, and 97 percent of this group uses text messaging. ${ }^{22}$ This group averages about 110 messages per day-or just under 8 per waking hour, and more than 3,200 per month. ${ }^{23}$ And a significant portion of teenagers-around 12 percent-claimed to be sending over 6,000 texts per month. ${ }^{24}$ Many teenagers have a hard time estimating how much of their day is spent texting because they use texts to participate in ongoing, written conversations with peers throughout the day. ${ }^{25}$

Texting is also the preferred means of communication between young adults and their peers. 63 percent of all teens say they exchange text messages every day with people in their lives. ${ }^{26}$ This far surpasses the frequency with which they choose other forms of daily communication, including phone calling by cell phone (39 percent do that with others every day); face-to-face socializing outside of school (35 percent); social network site messaging (29 percent); instant messaging (22 percent); talking on landlines (19 percent); and emailing ( 6 percent). ${ }^{27}$ In addition,

21. Rosalind S. Helderman, Click by Click, Teens Polish Writing: Instant Messaging Teaches More Than TTYL and ROFL, Wash. Post B01 (May 20, 2003).

22. Smith, supra n. 9.

23. Id.; see also Nielsen Newswire, New Mobile Obsession U.S. Teens Triple Data Usage, http://www.nielsen.com/us/en/newswire/2011/new-mobile-obsession-u-s-teens-triple -data-usage.html (Dec. 15, 2011) (noting that "messaging remains the centerpiece of mobile teen behavior" and that teens average seven text messages per waking hour) (hereinafter Nielsen Newswire, New Mobile Obsession].

24. Smith, supra n. 9.

25. See Raychelle Cassada Lohmann, Teen Texters: Are Teens TXTNG 2 Much? Psychol. Today (Mar. 14, 2011) (available at http://www.psychologytoday.com/blog/teenangst/201103/teen-texters).

26. Id.; Amanda Lenhart, Pew Research Center, Teens, Smartphones \& Texting, http://www.pewinternet.org/2012/03/19/teens-smartphones-texting/ (Mar. 19, 2012); see also Katie D. Anderson, Huffington Post, The Blog, Teen Texting: The Ruin of Romance, http://www.huffingtonpost.com/katie-d-anderson/teen-texting-the-ruin-of-romance_b_ 3763576.html (posted Oct. 10, 2013, 4:48 p.m.) (giving anecdotal evidence of the frequency of teen texting and how it is one long conversation).

27. Lenhart, supra n. 26. 
texting habits and preferences are fairly evenly spread over gender, race/ethnicity, household income, and education level. ${ }^{28}$

And while texting is used more often for informal checking-in with friends, almost half of texters claim to be sending texts "related to school work" at least a few times a week and to have long personal conversations. ${ }^{29}$ Young adults are also using texts more often to communicate with professors. ${ }^{30}$ In many ways, texting is more than the preferred means of communication for young people; it is becoming "an integral aspect of the sense of self for people who have grown up with this technology." 11

While teens are on the leading edge of mobile connectivity, "the patterns of their technology use often signal future changes in the adult population." 32 But though adults are texting more, young adults are increasing their use at a faster pace, and, therefore, the generational gap is widening. In 2011, adults between the ages of forty-five and fifty-four sent an average of one to ten texts per day, which was an impressive 91 percent increase in texting data used by this age group from the year before. ${ }^{33}$ But during that same time period, teenagers increased their use of texting data by 256 percent over the previous year, with almost one-third of teenagers averaging more than 100 texts per day. ${ }^{34}$ So while we may all be texting at increasing rates, our informal writing habits are unlikely to mirror our students' habits, making it less likely that we will appreciate the quantity of informal writing experience our students have prior to law school.

28. Smith, supra n. 9 (noting that non-whites text marginally more often than whites, and those with lower-level incomes and education text more often than those at the higher end of income and education). Although all texting numbers were down slightly in 2012, experts tie that decrease to an increase in Internet-based messaging services, like Apple's iMessage and Facebook messaging, because these services do not change per text. Brian X. Chen, N.Y. Times Bits Blog, Study Finds Rise in Texting Even as Revenue Drops, http://bits.blogs.nytimes.com/2012/11/26/pew-internet-study-texting/ (Nov. 26, 2012, at 5:57 p.m.).

29. See Amanda Lenhart et al., Teens and Mobile Phones 36 (Apr. 20, 2010) (available at http://pewinternet.org/Reports/2010/Teens-and-Mobile-Phones.aspx).

30. See id.

31. Skierkowski \& Wood, supra n. 7, at 746.

32. Mary Madden et al., Teens and Technology 2013, at 3 (Mar. 13, 2013) (available at http://www.pewinternet.org/Reports/2013/Teens-and-Tech.aspx).

33. Nielsen Newswire, New Mobile Obsession, supra n. 23.

34. Id. 


\section{THE IMPACT OF INFORMAL LANGUAGE ON STUDENTS' LANGUAGE ACQUISITION AND USAGE}

Many legal educators, attorneys, parents, and even students ${ }^{35}$ themselves view the rise of and reliance on informal writing through clenched teeth, dreading and tracking anecdotally its impact on our ability to write more formally as is required by legal discourse. Everything from errors in grammar and punctuation, to sloppy written work product, to misunderstandings caused by ill-conceived, quickly sent texts has been characterized as consequences of a "continuing assault of technology on formal written English." 36

The language and usage patterns of texting-or text speakdo look threatening to formal English. Texts typically consist of short, quickly composed and informally structured sentences, and often use an abbreviated vocabulary and initialisms ("LOL"), dropped words, emoticons, and contractions or shortened words. ${ }^{37}$ In addition, many texting platforms compensate for student mistakes and will automatically add apostrophes and fix misspellings, allowing students to rush through sentences without considering punctuation at all. And even if punctuation and grammar errors survive auto-correct, they will likely be viewed tolerantly by the texting audience, who expects only informal, conversational writing. By contrast, legal writing is formal, not only by tradition but by necessity: Attorneys must be careful readers, culling language for meaning and creatively considering the authorities' synthesized impact. Attorneys must carefully craft the language

35. See Michelle Drouin \& Claire Davis, R U Txting? Is the Use of Text Speak Hurting Your Literacy? $41 \mathrm{~J}$. of Literacy Research 46, 46 (2009) (finding that more than half of college-aged students studied indicated that they thought "text speak was hindering their ability to remember standard English"); see generally Brian J. Wardgya, The Relationship Between Text Message Volume and Formal Writing Performance among Upper Level High School Students and College Freshmen (Apr. 2012) (available at http://digitalcommons .liberty.edu/cgi/viewcontent.cgi?article $=1577 \&$ context=doctoral) (analysis based on data gathered fall 2011).

36. Lee, supra n. 15.

37. M.A. Drouin, College Students'Text Messaging, Use of Textese and Literacy Skills, 27 J. of Computer Assisted Learning 67, 67 (2011); see also Nancy Anashia Ong'onda et al., Syntactic Aspects in Text Messaging, 1 World J. of English Lang. 2 (Apr. 2011) (defining text messaging as "asynchronous text based technological mediated discourse that pursues simple sentences structure for communication"). Text speak is known for its characteristic use of abbreviations and syntactic reductions, see $i d$., but studies show that less than 20 percent of text messages use abbreviations of any kind, Crystal, supra n. 14, at 22. 
in legal instruments with the expectation courts will assume that kind of care when considering how to enforce them. And attorneys must produce professional briefs, knowing that courts (and clients) may reject clever arguments when they are sloppily presented.

This contrast between texting and legal discourse in style, purpose, and audience expectations may exacerbate what has already been for some students a difficult transition-or, students' increased writing experience (albeit informal) may smooth the way to learning another kind of writing. The following section discusses what studies of secondary and undergraduate school students predict about how frequent texting and the use of text speak will impact students' transition into expert writers and expert readers, and what it may tell us about the ability of our incoming law students to become expert legal writers and readers, with an appreciation of the law-trained reader.

\section{A. The Impact of Text Speak on Students' Becoming Expert Writers}

The data on the impact of frequent texting and the use of text speak on students' becoming expert writers offer a mixed bag to legal educators. On the one hand, frequent texting appears to have little impact on students' standard English language acquisition because students benefit from a growing metalinguistic awareness. This conscious awareness of language builds literacy generally, and may help law students specifically as they learn to address a new audience. But on the other hand, students who text frequently may demonstrate a habit for conciseness born out of a limited vocabulary rather than a precision of expression. And in another example of benefits and costs, while the informal nature of text speak may be creeping into student attitudes, contributing to a perceived decrease in professionalism, text speak also offers welcome practice in language play, something previously absent in legal education.

\section{Many Students Are Developing Two Literacies and the Metalinguistic Awareness to Switch between Them.}

Despite a widespread perception that frequent use of text speak is damaging our acquisition and usage of standard English, several recent, international studies have found no negative im- 
pact on language acquisition and literacy. ${ }^{38}$ These findings are consistent with a 2009 study of college students in the United States. ${ }^{39}$ This study found that students who frequently used text speak in their text messages showed no significant differences in standardized literacy scores (spelling, word recognition, reading fluency) or misspellings of common text speak words when compared to students who did not use text speak. ${ }^{40}$ From this data, the study's authors concluded that the use of text speak was not related to low literacy performance (although the study did recognize that the college students studied were old enough to have received a base of standard English instruction before they started using text speak). ${ }^{41}$

Other studies have actually found positive links between students' fluency with text speak and their fluency or success with standard English, and a "significant negative relationship" between improper use of text speak (like in emails to professors) and literacy and reading accuracy. ${ }^{42}$ A 2006-2007 study of a group of British pre-teenage children found that the more text speak children typically used in their text messages-or the more fluent they were in text speak-the higher they scored on tests of reading, vocabulary, and spelling. ${ }^{43}$ Today's youth appear to be building two literacies and "code-switching" or changing the language used to match the purpose and audience of the message. ${ }^{44}$

38. See e.g. Lucy Ward, Texting Is No Bar to Literacy, The Guardian (Dec. 22, 2004) (available at http://www.guardian.co.uk/technology/2004/dec/23/schools.mobilephones) (reporting on a study of British pre-teens that no text speak appeared in the texters' written work and attributing it to code-switching); see also Ong'onda, supra $\mathrm{n}$. 37 (finding through a study of forty college students' text messages that the use of text speak was intentional, even playful); see generally Crystal, supra n. 14, at 161 (listing international studies showing "that texting doesn't harm writing ability and may even help it").

39. Drouin \& Davis, supra n. 35, at 46 (studying 80 college students-34 text-speak users and 46 non-text-speak users).

40. Id.

41. Id. at 65. David Crystal believes that occasional text speak in written school work is evidence of carelessness rather than of any pernicious effect of texting on children. See Crystal, supra n. 14, at 152-153.

42. Drouin, supra n. 37.

43. Beverly Plester et al., Exploring the Relationship between Children's Knowledge of Text Message Abbreviations and School Literacy Outcomes, 27 British J. of Dev. Psychol. 145 (2009).

44. See Ward, supra n. 38. Code switching is explained in non-school contexts in NPR's Code Switch Blog. See e.g. Matt Thompson, NPR Code Switch Blog, Five Reasons Why People Code-Switch, http://www.npr.org/blogs/codeswitch/2013/04/13/177126294/fivereasons-why-people-code-switch (Apr. 13, 2013, 12:26 p.m.); Gene Demby, NPR Code Switch Blog, How Code-Switching Explains the World, http://www.npr.org/blogs/ 
Students who were not as successful at code switching-who used text speak in more formal communications, for example-had lower literacy scores. ${ }^{45}$ The data support the conclusion that children with strong language skills are not weakened by the frequent use of text speak, but that the exposure to text speak may be confusing weaker students.

This code-switching from informal text speak to more formal standard English is evidence of a growth in student metalinguistic awareness..$^{46}$ Metalinguistic awareness is a type of metacognition that requires a "keener than normal conscious awareness of language." 47 It is demonstrated by a manipulation of language, ${ }^{48}$ and it has been shown to have a significant effect on reading comprehension. ${ }^{49}$ It is, apparently, a welcome characteristic developed by many frequent texters. As evidence that students with strong language/writing skills are learning how to successfully move between literacies, in 2010, while students were texting more frequently and using more text speak in those texts, their relative use of text speak within other written contexts remained unchanged. ${ }^{50}$ Students who are successful at code switching used text speak in texts to friends, but not in emails to professors. ${ }^{51}$

codeswitch/2013/04/08/176064688/how-code-switching-explains-the-world (Apr. 8, 2013, at 9:14 a.m.).

45. Drouin, supra n. 37; see also Drouin \& Davis, supra n. 35, at 56 (noting that of the college students surveyed, 75 percent believed it was appropriate to use text speak in written communication with friends; only 6 percent said it was okay in communications with instructors).

46. See Plester et al., supra n. 43.

47. Susan Ebbers, Vocabulogic Blog, Metalinguistic Awareness, Comprehension, and the Common Core Standards, Vocabulogic, http://vocablog-plc.blogspot.com/2012/01/ metalinguistic-awareness-comprehension.html (Jan. 8, 2012).

48. Id.

49. Id.

50. See Drouin, supra n. 37; see also Brian J. Wardyga, A Relationship between Text Message Volume and Formal Writing Performance on the SAT, 2 J. Mass Comm. \& Journalism (2013) (available at http:/www.omicsgroup.org/journals/communication-as-a-socialprocess-2165-7912.1000e125.pdf) (analyzing texting's effect on grammar); Abbie Grace, et al., Undergraduates' Text Messaging Language and Literacy Skills, http://link.springer .com/article/10.1007/s11145-013-9471-2 (investigating the link between texting behavior and literacy skills in Canadian and Australian students); Lieke Verheijen, The Effects of Text Messaging and Instant Messaging on Literacy, 94 English Stud. 582 (2013) (available at http://www.tandfonline.com/doi/abs/10.1080/0013838X.2013.795737\#.UoY2pJRgZ7Q) (exploring conflicting studies on text messaging and literacy); Michelle Drouin \& Brent Driver, Texting, Textese, and Literacy Abilities: $A$ Naturalistic Study, J, of Research in Reading 1 (2012)) (exploring the relationship between texting and literacy in American undergraduate students).

51. Drouin, supra n. 37. 
A 2008 longitudinal study of one teenager-Lisa-who was a successful texter and a successful high school writer, emphasized this metalinguistic awareness as key in Lisa's ability to build both literacies. ${ }^{52}$ Lisa did not view her texting as writing; she viewed it as talking. ${ }^{53}$ Lisa was successful because she created two different writing worlds, or literacies; if she wrote longer texts, she would "code switch" and draw on her other writing skills. ${ }^{54}$ Lisa's experience demonstrates that students who are more successful writers are less likely to misuse text speak as they build this kind of metacognitive awareness. The broader studies suggest that while weaker students who are not able to code switch well may struggle with the appropriate use of text speak, many strong students are developing a conscious use of language and are able to manipulate it to meet the conventions of their medium.

\section{Texting May Be Narrowing Our Written Language.}

However, studies that show a positive link between texting and literacy also reveal a narrowness to texting and text speak that may put at risk the more expressive functions of written language. Students accustomed to the brevity demanded by a text may not be used to writing with detail or at any significant length, even when it may be warranted. For example, one study asked children to describe a picture or a situation, and the chil-

52. Jacobs, supra n. 12, at 203-211.

53. Id. at 207; but see Thomas Holtgraves \& Korey Paul, Texting Versus Talking: An Exploration in Telecommunication Language, 30 Telematics \& Informatics 289, 289 (2013) (available at http://www.sciencedirect.com/science/article/pii/S0736585313000038) (noting that the "highly interactive of texting sets it apart from [written and oral communication] modes").

54. Id.; see also Shazia Aziz et al., The Impact of Texting/SMS Language on Academic Writing of Students-What Do We Need to Panic About? 55 Ling. \& Trans. 12884, 12889 (2013) (available at http://www.elixirpublishers.com/articles/1360068938_55\%20(2013) \%2012884-12890.pdf) (concluding that "the concerns about the impact of SMS language on the academic writing of students and about standard language being in danger of destruction are exaggerated or misplaced"); Sarah De Jonge \& Nenagh Kemp, Text-Message Abbreviations and Language Skills in High School and University Students, 35 J. Research in Reading 49 (2012); William Kodom Gyasi, The 'SMS' Style of Communication: Effect on Language and Communicative Skills of Students of a Ghanian University, 1 Asian J. of Humanities \& Soc. Scis. 77 (2013) (available at http://ajouronline.com/index.php? journal=AJHSS\&page=article\&op=view\&path $\% 5 B \% 5 \mathrm{D}=188 \&$ path $\% 5 \mathrm{~B} \% 5 \mathrm{D}=165$ ); Ruben Infiesto, Jr. et al., The Relationship of SMS to the Writing Proficiency of the First Year Education Students of the University of Immaculate Conception, Arete 40 (2013) (available at http://research.uic.edu.ph/ojs/index.php/arete/article/viewFile/105/30). 
dren who regularly texted wrote significantly less than the children who did not regularly text. ${ }^{55}$

In addition to encouraging habitual conciseness, there is evidence that frequent texting limits our vocabulary. A 2011 study of college-aged students found that those with a frequent exposure to text messaging, as opposed to those with a more frequent exposure to traditional print media such as books and magazines, were less accepting of new words. ${ }^{56}$ Although text speak may seem to encourage unconstrained language experimentation, ${ }^{57}$ the study found instead that texters actually had a more narrow exposure to language. ${ }^{58}$ While reading traditional print media helps readers develop the tolerance for new words and a flexibility with language use, reading text speak exposes readers to a limited range of words. Text speak-even in its creativity and abbreviations-relies primarily upon familiar, common words. ${ }^{59}$

Legal discourse values conciseness, but a conciseness made possible through precision of expression. Texting's pairing of habitual conciseness and a limited vocabulary is troubling, and it presents the real obstacle to students' development into expert writers. Even if students become more adept at code switching between texting and other forms of discourse, they may lack exposure to broader language that would allow them to craft effective legal documents. Yet, while this consequence is a predictable risk of text speak, a diminished breadth of language acquisition is harder to measure than the students' ability to code switch between standard English and text speak. An error of code switching is obvious: a student drops some text speak into a formal document. But when a student fails to clearly articulate a legal issue, the problem may be the student has failed to adequately think through the issue, or the student lacks the vocabulary to articulate her reasoning with precision, or even that the student lacks the vocabulary to discipline her thinking. It is difficult to parse the cause and effect of language choice, and, therefore, it can be

55. See Ward, supra n. 38.

56. See Joan Hwechong Lee, What Does Txting Do 2 Language? The Influences of Exposure to Messaging and Print Media on Acceptability Constraints 104 (unpublished M.A. thesis, U. Calgary, Apr. 2011) (available at http://dspace.ucalgary.ca/bitstream/1880/ 48490/1/2011_Lee_MA.pdf).

57. See Crystal, supra $\mathrm{n}$. 1414, at 71-86 (describing language play in texting).

58. Lee, supra n. 56 , at 104.

59. Id. 
difficult to track students' weaknesses in this area. Although text speak is clearly less structurally complex and makes use of a limited vocabulary, ${ }^{60}$ "[d]istingishing between language change and language decline is very tricky business."61

In sum, while those of us in law teaching may have been attributing grammar and punctuation errors to the evils of frequent texting, the data do not support this link. Instead, students appear to be building two literacies and learning how to code-switch between them. But the weakness we should be watching for, and the more difficult weakness to diagnose and address, is the limited range of students' expression. As students transition to the language and patterns of legal discourse, we will likely need to address increased difficulties with word choice, with transitions, with subordinate clauses, and with a general hesitancy to address arguments with the requisite depth and precision.

\section{Texting May Give Students Valuable Practice in Language Play.}

But the nature of texting itself offers a potential counterbalance to its brevity and limited vocabulary: the inventiveness and playfulness texting introduces to students' experience with writing. Students who may in the past only have written for school or work are now regularly sharing (via text, tweet, or post) original "compositions" and are rewarded instantly by peers for clever language play. ${ }^{62}$

This experience in language play may address a perceived weakness in traditional legal writing instruction, particularly in its first year. To accustom students to the demands of a lawtrained audience and to meet certain pedagogical goals, law teachers typically limit students' early organizational and linguis-

60. See Ongonda, supra n. 37, at 3 (citing several studies that have documented the use of fewer subordinate clauses and a narrower range of vocabulary in text speak); Crystal, supra n. 14, at 167 ("Research reports also repeatedly draw attention to the reduced grammatical complexity of text messages ....).

61. Naomi S. Baron, Always On: Language in an Online and Mobile World 161 (Oxford U. Press 2008).

62. See Crystal, supra n. 14, at 71-86 (describing language play evident in both everyday texting and texting poetry competitions); Ong'onda, supra n. 37, at 3-6 (finding through a study of forty Kenyan college students' text messages that the use of text speak was intentional, even playful, and was starting to introduce variations in the language); see also Caroline Tagg, Scraping the Barrel with a Shower of Social Misfits: Everyday Creativity in Text Messaging, 34 Applied Linguistics 480, 497-498 (2013). 
tic choices, and students are rewarded for strict adherence to these requirements. As a result, many students feel their creative language choices are likewise limited, and they produce a bland (but organized) product.63 This narrowing at the beginning allows students and their teachers to separately assess attributes of effective writing, but the risk is that students, once narrowed, fail to expand upon the framework they have been given: "once these skills are mastered, they in fact may master the student, who finds it nearly impossible to think creatively and critically about the law, to have new ideas about it."64

With exposure to more creative writing opportunities, students may become better prepared to manipulate language and gain greater access to novel solutions, ${ }^{65}$ which will better prepare them for the creative demands of law practice. ${ }^{66}$ As students are ready to move beyond basic legal writing instruction, they are ready to experiment with creative word play. A logical beginning point in a traditional brief or memo is the statement of facts, because students know how to tell stories, but language-play exercises could extend to the questions presented, the brief answers, and to the larger argument of the brief. The language play introduced by texting and other informal writing gives students experience in creative expression that law teachers may draw upon.

\section{Frequent Use of Informal Writing May Be Related to a Perceived Drop in Professionalism.}

A final concern with texting's impact on composition is its association with a creeping lack of professionalism among students and practicing attorneys. In a 2012 survey of college and universi-

63. See Mary R. Falk, "The Play of Those Who Have Not Yet Heard of Games": Creativity, Compliance, and the "Good Enough" Law Teacher, 6 J. ALWD 200, 200-201 (2009); Barbara Stark, The Practice of Law as Play, $30 \mathrm{Ga}$. L. Rev. 1005, 1015 (1996); see generally Samantha A. Moppett, Lawyering Outside the Box: Confronting the Creativity Crisis, $37 \mathrm{~S}$. Ill. U. L.J. 253 (2013) (describing creativity generally, the declining creativity in the United States, and how legal educators can address these problems).

64. Falk, supra n. 63, at 201.

65. Id. at 200-201 ("But playing with ideas comes harder to these very smart authority junkies, and that's a shame, because it's through play that we find creative solutions and new directions."); Stark, supra n. 63, at 1015 ("Playing is doing.' Play requires repeated frustration, followed by repeated retreats to a holding environment, followed by yet another round of creative forays, of playful experiment.").

66. See Stark, supra n. 63, at 1017 (recognizing role-playing and storytelling as two examples of play demanded in the practice of law). 
ty professors, more than one-third reported that fewer than half of their upper-level students exhibited qualities associated with being professional in the workplace, and almost as many reported that this observation was consistent with a five-year decline in the number of students they viewed as demonstrating professionalism. ${ }^{67}$ The respondents blamed the drop in professionalism on many factors-including a perceived rise in students' sense of entitlement—but technology was blamed by a whopping 75.6 percent of those surveyed for a surge in unfocused students. ${ }^{68}$

Some claim that the rise in unfocused students is linked to another harm natural to the proliferation of quick, informal writing: that we are just exposed to too much bad writing and that the rise in bad writing will drown out good writing. As one commen. tator lamented, "Is the sheer fact that we are replacing so much of our spoken interaction with written exchanges gradually eroding a public sense that the quality of our writing matters?"69 Writing is not reserved for the formal confines of work anymore, and law teachers cannot ignore that students' increasing familiarity with informal writing will cause them to undervalue precise, careful writing.

Law teachers are positioned to positively impact students' valuation of precise writing. When formality and precision matter to the audience (the law teacher), they will matter to the student creating the product. This expectation should be justified by and reinforced with real-world examples of the consequences of poor writing, from ridicule from a court to malpractice suits. If good writing continues to matter anywhere, it will matter to attorneys and poets.

67. See Ctr. for Prof. Excellence at York College of Pa., 2012 Professionalism on Campus 16, http://www.ycp.edu/media/york-website/cpe/York-College-Professionalism-onCampus-Study.pdf (Jan. 2013) [hereinafter 2012 Professionalism Study]; see also Ann Schnoebelen, In Survey, Professors See a Lack of Professionalism among Students, Chron. Higher Educ. (Mar. 20, 2013).

68. 2012 Professionalism Study, supra n. 67, at 16-17.

69. Baron, supra n. 61, at 6-7 ("[T] he sheer amount of text that literate Americans produce is diminishing our sense of written craftsmanship. To rephrase Thomas Gresham, bad writing is driving good writing out of circulation."). 


\section{B. The Impact of Texting on Students' Becoming Expert Readers}

Of course students' writing abilities are inextricably linked to their reading abilities, and there are similar risks and rewards here. Students are reading more than ever, but students used to reading short bursts of conversational text may develop a casualness to reading that hinders their ability to become the active, expert readers legal analysis requires.

However, the data does not support this conclusion. Recent studies show that e-book reading is rising, especially among young people, and e-readers are consuming more content than they have in the past. ${ }^{70}$ In addition, reading comprehension-as measured by standardized tests-has risen (albeit marginally) since $1992 .^{71}$ Frequent exposure to informal writing does not appear to discourage students from reading longer documents. In 2009, the National Endowment for the Arts reported a nine-point growth rate since 2003 in the percentage of eighteen to twentyfour year olds who read literature. ${ }^{72}$ This rise in readers repre-

70. See Scholatic, Kids and Family Reading Report 4, http://mediaroom. scholastic.com/files/kfrr2013-wappendix.pdf (2013) (noting that the percent of children who read an e-book had doubled since 2010 (25 to 46 percent)); Lee Rainie et al., Pew Research Internet Project, The Rise of E-Reading, http://libraries.pewinternet.org/2012/04/04/therise-of-e-reading/ (Apr. 5, 2012) (reporting that more people are e-reading; thirty percent of those who read e-content say they now spend more time reading, and owners of tablets and e-book readers are particularly likely to say they are reading more since the advent of $e$ content).

71. U.S. Dept. of Educ., Natl. Assessment of Educ. Progress, The Nation's Report Card, Summary of Major Findings, http://nationsreportcard.gov/reading_2011/summary.asp (accessed Feb. 16, 2013) (summarizing reading test scores for fourth and eighth grades, showing a small but steady increase in reading scores since 1992); see also Hannah Withers \& Lauren Ross, McSweeney's, Young People Are Reading More Than You, $\mathrm{http} / / / \mathrm{www} \cdot \mathrm{mcsweeneys.net/articles/young-people-are-reading-more-than-you} \mathrm{(Feb.} \mathrm{8,}$ 2011) (summarizing NEA's two reports, see infra n. 72, and attributing the rise in young readers to Harry Potter). "The rise of screen-based media has not melted children's brains, despite ardent warnings otherwise." Id.; see also Kathryn Zickuhr et al., Pew Research Internet Project, Younger Americans' Library Habits and Expectations, http://libraries .pewinternet.org/2013/06/25/younger-americans-library-services/ (June 25, 2013) (eightytwo percent of Americans ages 18 to 29 say they have read a book in the past year); Lee Rainie \& Maeve Duggan, Pew Research Internet Project, E-Book Reading Jumps; Print Book Reading Declines, http:/libraries.pewinternet.org/2012/12/27/e-book-reading-jumpsprint-book-reading-declines/ (Dec. 27, 2012); Lee Rainie \& Aaron Smith, Pew Research Internet Project, Tablet and E-reader Ownership Update, http://pewinternet .org/Reports/2013/Tablets-and-ereaders/Findings.aspx (Oct. 18, 2013).

72. Natl. Endowment for Arts, Reading on the Rise: A New Chapter in American Literacy 4, http://www.nea.gov/research/readingonrise.pdf (2009) [hereinafter Natl. Endowment, Reading on Rise]. Six years earlier, by contrast, eighteen to twenty-four year olds 
sented 3.4 million additional readers, and the rate of their rise as readers (a 21 percent increase since 2002) is greater than for any other age group and three times the growth rate of all adult readers. ${ }^{73}$ Another study of children's media habits concluded that "[i]t does not appear that time spent using screen media (TV, video games and computers) displaces time spent with print media."74

A 2012 Pew Internet and American Life Project study supported the finding that young readers are reading more long-form texts, like books. ${ }^{75}$ Americans under the age of twenty-four read more books than any other age group, and Americans under the age of thirty are more likely than older adults to do any kind of reading (books, magazines, journals, newspapers, and online content), and to do it for work or school or just to satisfy their own curiosity. ${ }^{76}$

As for the specific impact of texting on reading, the studies that show a positive connection between texting literacy and standard English literacy also show a positive connection with reading attainment. ${ }^{77}$ Students appear to benefit from an increased exposure to written word and an improved motivation to engage with written communication outside of the constraints and expectations of school assignments. ${ }^{78}$ The students with a high ratio of text speak in their text messages also showed increased phonological awareness - an ability to identify the variety of sound units in individual words-which is linked to reading attainment. ${ }^{79}$ One study's authors concluded, based on their data and on a review of the studies available, that there was "no compelling evidence to support the negative statements made in the

had shown the steepest rate of decline in reading since the NEA survey began. See Natl. Endowment for Arts, Reading at Risk: A Survey of Literary Reading in America, at xi, http://arts.gov/sites/default/files/ReadingAtRisk.pdf (June 2004).

73. Natl. Endowment, Reading on Rise, supra n. 72, at 4.

74. Id. Victoria J. Rideout et al., Generation $M^{2}$ : Media in the Lives of 8- to 18-YearOlds 35 (Kaiser Fam. Found. Jan. 2010) (available at http://kaiserfamilyfoundation.files .wordpress.com/2013/04/8010.pdf).

75. Kathryn Zickuhr et al., Pew Research Internet Project, Younger Americans' Reading and Library Habits, http://libraries.pewinternet.org/2012/10/23/younger-americansreading-and-library-habits/ (Oct. 23, 2012) (attributing much of the increase to e-readers).

76. Id.

77. See Plester et al., supra n. 43 , at 147.

78. Id.

79. Id. at 147,155 (making the conclusions after controlling for individual differences in age, short-term memory, vocabulary, phonological awareness and how long they had owned a mobile phone). 
media regarding how children's written language development is being disrupted by exposure to text abbreviations." 80

Although slightly off the topic of texting, a nonetheless critical consideration of students' development into expert readers is their almost constant exposure to an immense amount of information. Although the nature of legal research has for decades demanded that lawyers navigate stacks (digital or otherwise) of research and synthesize it into a coherent analysis, the "stacks" are now a flood of information, which may overwhelm and confuse researchers. Students are receiving more instruction, prior to law school, on digital literacy, and law teachers are adapting to the new information literacy, ${ }^{81}$ but most teachers believe that the ability to access so much information is creating weaker, more distracted researchers. ${ }^{82}$

\section{Expert Writers, Expert Readers, and Consideration of Audience}

While students may struggle with gaining knowledge in the sea of information available to them, the interactive nature of online content may make them more open to a key characteristic of expert readers and writers: the willingness to view the relationship between reading and writing, and between the author and the audience as "transactional." 83 Expert writers and readers reflect upon and respond to text while considering the rhetorical concerns of the other-the writer or the reader. ${ }^{84}$ This "reflective quality" makes them more able to question writing, to respond to it, and to solve problems; they "learn more from experience and

80. Id. at 158 .

81. See generally Ellie Margolis \& Kristen E. Murray, Say Goodbye to the Books: Information Literacy as the New Legal Research Paradigm, 38 U. Dayton L. Rev. 117 (2012).

82. Kristin Purcell et al., Pew Research Internet Project, How Teens Do Research in the Digital World, http://www.pewinternet.org/2012/11/01/how-teens-do-research-in-the-digital -world/ (Nov. 1, 2012) (finding that 87 percent of secondary school teachers said the internet and digital technologies are creating an "easily distracted generation with short attention spans," and that 64 percent said today's digital technologies "do more to distract students than to help them academically"); cf. Brittany Stringfellow Otey, Millennials, Technology, and Professional Responsibility: Training a New Generation in Technological Professionalism, 37 J. Leg. Profession 199, 227-228 (2013) (describing how instructors should adapt their teaching to engage and prepare students for the increased demands of a technologically driven practice).

83. Linda L. Berger, Applying New Rhetoric to Legal Discourse: The Ebb and Flow of Reader and Writer, Text and Context, 49 J. Leg. Educ. 155, 162-163 (1999).

84. Id. at 163 . 
add to their ways of understanding new reading and writing." 85 Instead of focusing on simple "knowledge getting," expert readers "try[ ] to imagine a real author with a specific purpose," and expert writers "work within a rhetorical framework that includes 'imagining audience response, acknowledging context and setting their own purposeful goals." 86

This attention to audience is key to legal discourse, which is "a dialogue by its nature, not a monologue. No one speaks or writes to himself." 87 Students who text frequently have practice using writing as part of a dialogue; texting began to thrive among young people as an index of belonging to and communicating with a peer group. ${ }^{88}$ Data demonstrate that students who access social media, including texting, often have an increased appreciation for the dialogue of discourse because they are familiar with almost immediate communication with audience.

Blogging in particular seems to build students' sense of audience. A 2011 study of elementary school children reported that, at the beginning of the school year, the children had a weak sense of audience; it was an "abstract concept and, as such, was given little attention." 89 Their writing was self-centered and focused on the writers' own needs as learners and writers, and it did not consider the needs of the reader. ${ }^{90}$ After students had a year's worth of experience with a classroom blog that included an active commenting feature, students were more likely to "address[ ] their audience with care and attention." 91 Students consequently wrote with a "more powerful voice," and their "writing became more independent and confident." 92

85. Id.

86. Id. (quoting Christina Haas \& Linda Flower, Rhetorical Reading Strategies and the Construction of Meaning, 39 C. Comp. \& Comm. 167 (1988)).

87. Aulis Aarnio, Essays on the Doctrinal Study of Law 101 (Springer 2011).

88. See Crystal, supra n. 14, at 93; see also Carolyn R. Miller \& Dawn Shepherd, Into the Blogosphere: Rhetoric, Community \& Culture of Weblogs, Blogging as Social Action: A Genre Analysis of the Weblog, http://blog.lib.umn.edu/blogosphere/blogging_as_social _action_a_genre_analysis_of_the_weblog.html (posted Sept. 25, 2004, 3:17 p.m.) (explaining that blogs took off in large part to meet the need for an audience).

89. Ewa McGrail \& Anne Davis, The Influence of Classroom Blogging on Elementary Student Writing, 25 J. of Research in Childhood Educ. 415, 425 (2011).

90. Id.

91. Id at 426; see also Amanda O'Connor, Instant Messaging: Friend of Foe of Student Writing?http://education.jhu.edu/PD/newhorizons/strategies/topics/literacy/articles/instantmessaging/ (May 5, 2010) (opining that the most important thing to emphasize with texting students is audience).

92. McGrail \& Davis, supra n. 89. Teachers also reported that students who partici- 
This increased attention to audience is the most promising characteristic a frequent texter brings to the legal writing classroom because it is the key that unlocks the other benefits informal writing expertise offers a developing legal writer and reader. Students who consider a law-trained audience are more likely to code-switch to address that reader appropriately; they are more likely to use creative word play appropriately and effectively; and they are more likely to create a professional document, even if it is an email.

\section{TEXTING'S IMPACT ON THE FRICTION OF WRITING}

Writing is hard, problem-solving work-and expert writers say it should be. ${ }^{93}$ The effort of writing requires us to solve knowledge problems (where a writer must synthesize or integrate source information into a cohesive analysis), language problems (where writers know what they want to say but struggle to find the right words), and rhetoric problems (where writers struggle with their purpose and their audience). ${ }^{94}$ Expert writers use the friction between the ideas in their heads and the construct of a written text to solve these problems, to build meaning, and to create knowledge. ${ }^{95}$ Writing becomes a disciplined creative activity, exploratory and recursive, so-through revision-it moves the writer towards a strong, final product.

Texting is quick, conversational writing done on a keyboard (albeit a small one), and students adept at and familiar with texting may have less friction of composition. Students are swimming through seas of bad prose and good prose, much of which may seem to have the same face value. When writing is familiar and easy, students may be less able to see the work good writing requires. This may be the cost of fast: that students do not recognize good writing and do not work hard to create it. When this

pated in the classroom blog viewed writing as empowering, rather than just as school work. See infra pt. V.

93. See Erika Lindemann, A Rhetoric for Writing Teachers 25 (3d ed., Oxford U. Press 1995) (characterizing her work to create a first draft as "agonizing effort, painstaking word-for-word labor that only here and there satisfactorily expresses what I have to say").

94. See id.at 28.

95. See Berger, supra n. 83, at 157 ("Knowledge and truth are created by the process, rather than existing outside the process."); Chris Guthrie et al., Blinking on the Bench: How Judges Decide Cases, 93 Cornell L. Rev. 1, 7 (2007). 
happens, the writing process ceases to force understanding and knowledge.

But there may also be a gain of fast: that we are better able to write without thinking about writing. Experts have long encouraged writers to use unplanned freewriting to move past language and rhetorical problems and to focus on creating understanding and producing creatively.

\section{A. The Loss of Slow}

When author Nicholson Baker wants to understand or reflect upon the words of others, he copies out passages longhand; he relies on the slowness of handwriting to "retard[ ] thought's due process" and to "push every competing utterance away." 96 Novelist John Irving handwrites all of his drafts because "[i]t's the right speed." 97 Susan Sontag and Truman Capote also preferred the slowness of writing for their early drafts. ${ }^{98}$

Attorneys are professional writers, but most clients will not pay for their counsel to "carve out scupperfuls of time" 99 by handwriting an argument. This pacing is unrealistic for most of us; one expert predicted that "the ability to read one thing and think hard about it for hours will not be of no consequence [in the near future], but it will be of far less consequence for most people."100 Instead, most experts predict that the ability to quickly assess the quality of information and then to synthesize it will be an essential skill. ${ }^{101}$ But surely we should worry that we are eliminating the tools that give time for reflection and the "working-through" that is critical to thoughtful analysis and is especially critical for students learning the craft. Writing by hand has, for centuries,

96. Baron, supra n. 61, at 197 (quoting Nicholson Baker, Narrow Ruled 5 (Am. Scholar 2000))

97. John Irving, What Book Is on Your Night Stand Now? N.Y. Times BR8 (June 10, 2012) (available at http://www.nytimes.com/2012/06/10/books/review/john-irving-by-thebook.html?pagewanted=all\&_r=0).

98. See Chris Gayomali, 4 Benefits of Writing by Hand, The Week (Jan. 16, 2013) (available at http://theweek.com/article/index/238801/4-benefits-of-writing-by-hand) (asserting that writing by hand is better for learning, makes you a better writer, prevents you from being distracted, and keeps your brain sharp).

99. Baron, supra n. 61, at 197.

100. Anderson \& Raine, supra n. 13 (quoting prediction of Jonathan Grudin, principal researcher at Microsoft).

101. Id. (summarizing predictions of surveyed technology experts and stakeholders in future of education). 
been the tool that slowed down racing thoughts and permitted half-formed or unexpected ideas to develop. ${ }^{102}$

There is another concern besides the potential increased pace of our composition. Writing may be diminishing in its role as a medium for clarifying thought because writers now, with their exposure to informal writing, have a decreased concern for the structure of writing: the "prescriptive rules" of writing and the need for "linguistic consistency." 103 "If 'good' and 'bad' writing bear the same face value, motivation to struggle to produce 'good' prose diminishes." 104 As a specific example, PowerPoint dominates the presentation of ideas and professional writing. Through preformatted slides and graphics, it threatens to "squeez[e] out" the creative, free flow of ideas and proof in favor of order and text dumping. ${ }^{105}$

Not only may an increased speed of composition be decreasing the time we need to develop ideas, it may also be encouraging writers to sacrifice accuracy for expediency. Authors of a 2009 study of 300 children ages eleven to fourteen found that kids who used mobile phones performed faster on a battery of cognitive tests, but they also made significantly more errors. ${ }^{106}$ The authors hypothesized that the frequent use of the devices makes kids fast and sloppy, and may even be rewriting young brains. ${ }^{107}$ "The convenience of electronically-mediated language is that it tempts us

102. Lindemann, supra n. 93, at 27. Not addressed here, but interesting, is the work of Virginia Berniger on the impact handwriting has on the learning of young children. See e.g. Gwendolyn Bounds, How Handwriting Trains the Brain, Wall St. J. (Oct. 5, 2010) (available at http://online.wsj.com/article/SB10001424052748704631504575531932754922 518.html) (summarizing Berniger's work showing that sequential finger movements used in handwriting activate "massive regions" of the brain involved in thinking, language and working memory-the system for temporarily storing and managing information).

103. Baron, supra n. 61 , at 168 (distinguishing the prescriptive rules that dominate written speech from the descriptive rules of oral communication).

104. Id. at 184.

105. Ian Parker, Absolute Powerpoint, New Yorker (May 28, 2001) (available at http://www.newyorker.com/archive/2001/05/28/010528fa_fact_parker\#ixzz2PBe8OPsm)

(quoting a college professor who admitted cutting a book from his syllabus because he could not figure out how to PowerPoint it).

106. Gary Small, Is Texting Making Us Stupid? Psychol. Today (2009) (available at http://www.psychologytoday.com/blog/brain-bootcamp/200908/is-texting-making-usstupid); see Carr, supra n. 5; Nicholas Carr, The Shallows: What the Internet Is Doing to Our Brains (W.W. Norton 2010).

107. Small, supra n. 106. 
to make a Faustian bargain of sacrificing thoughtfulness for immediacy." 108

It is, of course, not only the speed of communication and the ease of writing that weakens the depth of our analysis; in our always-on culture, we are consistently assaulted with information. Meaningful learning requires sustained attention to material over time. Predictably, a 2012 study of school-aged youth found that students who text and check Facebook frequently (the two most common communication technologies accessed) during studying performed more poorly than students who did not. ${ }^{109}$ The frenetic cognitive style is a consistent concern of those who wish to encourage considered, thoughtful analysis.

\section{B. The Gain of Fast: Freewriting}

Ironically, while we worry that the speed of writing may keep a writer on the surface of an analysis, quick writing is regularly used by writers to generate ideas and to build cohesion between them. Freewriting is the act of producing unplanned language and unplanned thinking; it is exploratory writing, rather than communicative writing, and writers use it to solve problems. ${ }^{110}$ Professor Peter Elbow, a nationally known figure in teaching writing and an advocate of freewriting, says, "I'll get into a little tangle that I can't figure out and I'll just lapse into freewriting. I'll just write, write, write, write until I can clear up the tan-

108. Id.; see also Baron, supra n. 61, at 198-199 ("In principle, there is no reason we can't do some writing the old-fashioned way: multiple drafts, time between them to think, a couple of rounds of proofreading. In practice, though, word processing programs beckon us to push 'print,' while email entices us to hit 'send."').

109. See Reem Alzahabi \& Mark W. Becker, The Association between Media Multitasking, Task-Switching, and Dual-Task Performance, 39 J. Experimental Psychol. 1485 (2013); Dennis E. Clayson \& Debra A. Haley, An Introduction to Multitasking and Texting: Prevalence and Impact on Grades and GPA in Marketing Classes, 35 J. Mktg. Educ. 26 (2013) (available at http://jmd.sagepub.com/content/35/1/26.short); Reynol Junco \& Shelia R. Cotton, No A 4 U: The Relationship between Multitasking and Academic Performance, 59 Computers \& Educ. 505 (2012); but see Scott T. Frein et al, When It Comes to Facebook There May Be More to Bad Memory Than Just Multitasking, 29 Computers in Human Behavior 2179 (2013) (available at http://www.sciencedirect.com/science/ article/pii/S074756321300143X).

110. See Peter Elbow, Freewriting, Voice, and the Virtue of Making a Mess: A Conversation with Peter Elbow, 17 Issues in Writing 1, 1-2 (2007-2008); see also Elizabeth Fajans \& Mary R. Falk, Scholarly Writing for Law Students: Seminar Papers, Law Review Notes, and Law Review Competition Papers 37-38 (3d ed., Thomson/West 2005) (recommending freewriting and journal writing to generate ideas and "raw creativity" and to prevent writer's block). 
gle."111 When it works, freewriting focuses the writer on solving the first problem of writing-creating knowledge-by releasing the writer from rhetorical concerns of translating those ideas into correct language. ${ }^{112}$ Freewriting can remove the writer's anxiety of evaluation that often attends real writing, while it can encourage "raw creativity."113 Freewriting also acts to improve connections between ideas, because "speed lends itself to coherence."114

Elbow describes two kinds of writers who are helped by freewriting: For "the scrunched writer," who struggles with words and is forced to put down something, freewriting may provide a space free from the constraints of formal composition, where a writer may develop more powerful language and may nurture ideas. ${ }^{115}$ For the "rounded fluent writer" who is good at making the quick decisions involved in writing, freewriting may put a helpful resistance or friction into his or her writing by separating thought-generation from composition. ${ }^{116}$

Of course there are important differences between freewriting and texting: Freewriting is exploratory because its aim is to build the writer's knowledge rather than to communicate to an audience; ${ }^{117}$ texting is direct communication, usually informal and uncomplicated. But they share a characteristic that may help students familiar with texting build a "freewriting muscle"118 to deepen their analysis: Both freewriting and texting encourage students to compose quickly without thought for structure.

Students are not likely to make this connection and use their texting skills to freewrite without specific direction and modeling.

111. Peter Elbow, Writing with Power: Techniques for Mastering the Writing Process (Oxford U. Press 1981).

112. See id. at $15-16$.

113. Elizabeth Fajans \& Mary R. Falk, Comments Worth Making: Supervising Scholarly Writing in Law School, 46 J. Leg. Educ. 342 (1996); see also Elbow, supra n. 107 (" $[\mathrm{P}]$ eople have to learn to write a lot, to write garbage. People, especially academics, are scared of writing badly. But when things don't go well, when people don't write enough, it's usually because they aren't writing badly enough. You probably know the advice of William Stafford: 'When I have trouble writing I just lower my standards.").

114. Elbow, supra n. 111, at 15 (listing other rewards of regular freewriting as making the writing process transparent and moving the writer past translating, to understanding and producing creatively).

115. Id. at 18 .

116. Id. at 19 .

117. Id. at 99-100 (explaining that when writing is used as a way to work out as a process of exploration and discovery, you do not have to think carefully about it as writing, and that this writing as exploration usually helps your writing as communication).

118. Elbow, supra n. 110. 
Throughout the writing process, students should be encouraged to use their writing fluency to build understanding and to work through knowledge problems. For example, students beginning a research project often fail to adequately consider the facts of the assigned problem. They identify the key legal issue asked, and then launch into research to learn all they can about that legal issue. To help students research from the facts, students may be asked to read the assigned problem, identify the legal issue, and then freewrite about the facts: which facts are likely to be relevant to the courts' decision on the legal issue, which facts seem unique and problematic. Students who have done this are more likely to generate ideas about the ways the law will apply to the facts, and then are more likely to see nuances in their research. ${ }^{119}$

\section{PROBLEMS OF TRANSFER AND THE PROMISE OF ASSOCIATING STUDENTS WITH A COMMUNITY OF WRITERS}

But most students - even those successful in both texting and more formal writing-do not view texting as experience in a discourse community that could give them broader competence. While young adults spend much of their lives composing texts, and they recognize that writing skills are critical to educational success, they do not view what they are doing as real writing practice. ${ }^{120}$ If they consider at all the impact texting may have on their writing, they assume it must be negative: that their standard linguistic abilities have been affected by their knowledge and use of text speak. ${ }^{121}$ Although this assumption is not supported by the data, the perception that texting has a negative impact on writing may be more important than texting's actual impact. ${ }^{122}$

119. Elbow, supra n. 111, at 95-98 (suggests using writing to work through problems, to remember key concepts, to improve trains of thoughts, and to work through stuck points).

120. See Amanda Lenhart et al., Writing, Technology, and Teens, http://pewinternet .org/ /media/Files/Reports/2008/PIP_Writing_Report_FINAL3.pdf.pdf (Apr. 24, 2008) (reporting that many teens still link writing to formal settings, like school; texting is more like a "conversation"); Kristen Purcell et al., The Impact of Digital Tools on Student Writing and How Writing is Taught in Schools, Pew Internet \& Am. Life Project, http://pewinternet.org/Reports/2013/Teachers-technology-and-writing-aspx (July 16, 2013).

121. See Skierkowski \& Wood, supra n. 7, at 747.

122. See id. 
If students see texting as speaking, and not writing, they are less likely to transfer any skills they have developed in informal writing to more formal writing. Our goal as legal educators should be to facilitate the transfer of problem-solving and composition skills from the students' past experience to their current writing problems, and from our current instruction to future writing problems. Although the goal of all education is transfer, ${ }^{123}$ skills gained in one kind of writing (texting) will not automatically transfer to other kinds of writing (formal legal discourse). Indeed, "' $[t]$ o the extent that transfer does take place, it is highly specific and must be cued, primed, and guided; it seldom occurs spontaneously."'124 So, although more writing exercise may be good for us, and may improve our awareness of the needs of our audience and how to meet them, "merely churning out text is hardly the best way to improve your writing." 125 "[S]inging off-key in the shower each morning doesn't increase your chances of making it to La Scala." 126

The first step in transferring any knowledge and abilities gained from informal writing experience to more formal writing experience is to instruct students on broader similarities-or "mental grippers"-between two kinds of writing. ${ }^{127}$ Mental grippers are the abstract concepts-such as a "discourse community"-learners can identify in a specific discourse (like texting) and then identify in another domain (like legal writing). Mental grippers allow students to solve composition problems by reminding them how they solved the same problems in other contexts. For example, once students recognize that texting has its own dis-

123. Anne Beaufort, College Writing and Beyond: A New Framework for University Writing Instruction 149 (Utah St. U. Press 2007); see David N. Perkins \& Gavriel Salomon, Teaching for Transfer, 46 Educ. Leadership 22 (1989).

124. Beaufort, supra n. 123, at 150 (quoting Perkins \& Solomon, supra n. 123).

125. Baron, supra n. 61, at 198; cf. Crystal, supra n. 14, at 158 ("I believe that any form of writing exercise is good for you. I also believe that any form of tuition which helps develop your awareness of the different properties, styles, and effects of writing is good for you. It helps you become a better reader, more sensitive to nuance, and a better writer, more sensitive to audience. Texting language is no different from other innovative forms of written expression that have emerged in the past. It is a type of language whose communicative strengths and weaknesses need to be appreciated.").

126. Baron, supra n. 61, at 198.

127. Beaufort, supra n. 123, at 151 ("If we want to promote the transfer of certain kinds of writing abilities from one class to another or to one context to another, then we are going to have to find the means [to instruct on the] similarities between the way writing is done in a variety of contexts." Id. at 149 (citation omitted)). 
course community whose members have certain rhetorical expectations, they are more likely to appreciate that legal writing similarly has its own discourse community whose expectations students will also need to learn. ${ }^{128}$ As students develop towards becoming experts, they "shift their basis for categorizing problems from relatively surface attributes of problems to more abstract, structural attributes that cue principles relevant to the solution."129

There are broader pedagogical benefits when students connect writing they have done with writing they will have to do. Research in other artistic disciplines indicates that when young people recognize they are part of a community, they are generally more willing to take the rules of that community and transfer those rules to other learning. ${ }^{130}$ Novice legal writers are particularly prone to feeling that their past writing experience is irrelevant to the unique organizational demands and argument constructs of legal discourse; "[t]heir [consequent] discouragement, and the anxiety that often accompanies it, can produce profound self-doubt, and, for more than a few, a kind of writing paralysis." 131

So exercises that cue, prime, and guide transfer will improve students' awareness of the linguistic choices they are making; will make it more likely that any skills or knowledge they gain from writing-whether it be informal or formal writing-accrues to other, unrelated writing tasks; and will improve students' confidence by identifying elements of their past writing that are relevant to current tasks. ${ }^{132}$ Such exercises may include responsive journals, which force the students to respond to the rhetorical goals of the cases they are reading and to consider how those rhetorical goals align with their own; we may assign personalexperience essays, which allow students to write more informally.

128. Id. at 151 .

129. Id. (citation omitted).

130. See Shirley Brice Heath, Learning Language and Strategic Thinking through the Arts, 39 Reading Research Q. 338, 339 (Sept. 2004) (positing that when young people are part of a community, even one outside of school, they are generally more ready to take in information and commit to the rules of "the artistic community" that will transfer to other learning).

131. Andrea McArdle, Teaching Writing in Clinical, Lawyering, and Legal Writing Courses: Negotiating Professional and Personal Voice, 12 Clin. L. Rev, 501, 502-503 (2006).

132. See McGrail \& Davis, supra n. 89 (reporting that students who participated in the classroom blog viewed writing as empowering, rather than just as school work). 
And it may be that we simply engage our students in conversations about the writing they do and the language choices they make in that writing.

\section{CONCLUSION}

We may be panicked, even morally outraged, by the rise of texting, but we should react to (and prepare for) the right threats. While the data do not support the fear that texting is weakening standard English skills, texting may in fact be narrowing our language and our expression. More troubling, texting and the resulting ease of composition may be speeding us past the thoughtful consideration necessary for careful problem solving, the kind of knowledge-building that the friction of more formal composition encourages.

However we should recognize (and encourage) the potential benefits of students who are frequent texters. Texting and other informal writings are often creative and fun, which means students may have an appreciation for word play that is underemphasized in law-school curriculum. In addition, fast writing may be channeled into freewriting, which could build the thoughtful generation of ideas into students' writing. Finally, importantly, helping students see that, through their informal writing, they have already become members of one community of writers may help reduce their anxiety as they learn to address law-trained readers.

There is no going back. Our technology is eliminating barriers to expression-writing is easier than ever in the past-and we must be familiar with our students' habits and be prepared to help them transfer skills they may have to the new writing challenges they will face. 